\title{
Improving the Teaching Ability of Dance Major Courses
}

\author{
https://doi.org/10.3991/ijet.v16i04.20477 \\ Fubo Ma \\ Northeast Agricultural University, Harbin, China \\ fuboma@126.com
}

\begin{abstract}
To improve the teaching ability of dance major courses, special attention should be paid to the following factors: the completeness of the evaluation index system (EIS), the fuzziness and uncertainty of the evaluation process, and the reliability and accuracy of the evaluation. Considering these factors, this paper summarizes the connotations and essential features of the teaching ability of dance major courses, and explores deep into the factors affecting that teaching ability. On this basis, the authors created a series of improved EISs and constructed an improved model for the evaluation of the teaching ability of dance courses, drawing on entropy method and grey theory. The proposed model enables dance teachers to improve their ability to teach dance major courses. The research results lay the theoretical and practical bases for the teaching reform in the dance major of colleges.
\end{abstract}

Keywords-Teaching ability, dance major courses (dance courses), evaluation index system (EIS), information entropy, grey theory

\section{Introduction}

As modern science and technology is developing rapidly and people's living standards are improving continuously, modern education is now paying more attention to the cultivation of professional talents; in the context of quality education, cultivating professional talents with high comprehensive qualities has become an important goal for modern education [1-4]. As an important part of modern education, dance teaching plays a promotive role in improving the level of quality education [5-6], and one important factor for enhancing the competitiveness of dance majors and cultivating highlevel dance professionals is the teaching ability of dance major courses. However, the improvement of the teaching ability of dance courses is a complex systematic project that requires us to comprehensively consider various constraints, in particular, how to effectively evaluate and analyze the teaching ability of dance courses directly affects the improvement of the course quality [7-8]. Aiming to improve the dance teaching ability of kindergarten normal students, TANG explored methods and strategies to improve the dance teaching ability of kindergarten normal students [9]. To improve the teaching ability of dance courses, SHI analyzed from the aspects of dance teaching concept innovation, dance foundation training, choreography theory teaching, and choreography learning environment creation [10]. Serafina Pastore et al. discussed a 
conceptual method of teaching practice analysis and explained it with specific cases, which provided a good reference for the improvement of dance teaching ability [11]. SHI discussed the evaluation of physical dance education with improving the teaching ability of physical dance education as the research purpose, which provided a theoretical basis for the improvement of the teaching ability of PE dance courses [12].

In regards of the complex and dynamic features of the evaluation process of the teaching ability of dance courses, as well as the fuzzy and uncertain information contained in the evaluation process, how to establish a set of evaluation systems and models suitable for improving the teaching ability of dance courses is of very important research significance. Although the existing evaluation methods have a good application background [13-16], still they have certain limitations, such as some are subjective, some require a huge amount of data for training and analysis, and some have very complicated computation processes, etc. For this reason, based on the existing research results, this paper analyzes the essential issues concerning the improvement of the teaching ability of dance courses drawing on the entropy method [17-18] and gray theory [19-20], and makes a further discussion on the improvement of the teaching ability of dance courses.

The research content of this paper includes six parts. The first part summarizes the research content of the teaching of dance courses, and summarizes and compares the existing research results. The second part discusses the connotation and essential features of the teaching ability of dance courses. The third part analyzes factors affecting the teaching ability of dance courses. The fourth part establishes a series of EISs for evaluating the teaching ability of dance courses. The fifth part gives an evaluation model for the teaching ability of dance courses. The sixth part gives the conclusions.

\section{Essential Features of the Teaching Ability of Dance Courses}

Compared with other technology-oriented majors or majors of applied science, the teaching of dance major is quite different; on the one hand, dance major requires a good knowledge background of professional theories and high-level professional dance literacy, which is affected by various factors such as the cultural background, growth experience, spirits and temperament, etc.; on the other hand, although dance major generally does not require special application conditions, its teaching development often has obvious features of the times and it is a dynamic and sustainable development process. Therefore, we need to probe deep into the connotation of the teaching ability of dance courses and explore its essential features, so as to improve the teaching ability of dance courses. The authors hold that, the essential features of the teaching ability of dance courses are reflected in the following aspects:

\subsection{Mastery of the teaching philosophy}

The teaching concept of dance courses is the epitome of dance major knowledge; therefore, it requires a good dance major background and professional dancing literacy, which reflected the teaching ideas, views, attitude and concept of the dance teach- 
ers or administrators, and it is also the beliefs held by dance educators during the teaching of dance courses. Therefore, adopting advanced teaching concept, clarifying the development direction of teaching concept, and clearly expressing the teaching concept of dance courses have very important guiding significance for carrying out the teaching activities of dance courses. To this end, in terms of the mastery of the teaching concept of dance courses, it's necessary for the professional dance teachers and administrators to do a good job in aspects of teaching theory, teaching implementation, and construction of disciplines and majors, etc.; moreover, they also need to formulate reasonable teaching goals and development plans for dance courses, scientifically carry out dance teaching activities, and provide good support for cultivating high-level professional dance talents.

\subsection{Construction of teaching system}

Constructing a teaching system for dance courses is a complex and systematic project, which not only needs to take various factors in the implementation links of teaching activities into consideration, but also needs to pay attention to all kinds of influencing factors in aspects such as the organization of the teaching of dance courses, the preparation before class, and the feedback and communication after class. At the same time, it can be seen from the operation process of these implementation links that these links have close logical and systematic relationships, and they are complementary and can promote each other. If we can well manage the correlations among these links, it'll be helpful to the implementation of teaching tasks and the completion of teaching progress of dance courses, and it's also conductive to carrying out the teaching activities, and thereby fully reflecting the teaching ability of dance courses. Meanwhile, in terms of the cultivation process of dance major students, we need to train the students to have not only a solid theoretical knowledge background of the dance profession, but also excellent dancing skills, strong body functions, good musical sense, and higher cultural qualities, etc., and the teaching of such contents should also be included into the entire teaching system, so that the teaching system of dance courses can be more integrated, complete and consistent.

\subsection{Cultivation of teaching ability}

The teaching ability of dance teachers is the most basic and direct manifestation of the quality of dance courses. From the perspective of the teaching ability of dance courses, the higher the teaching ability of dance teachers, the more dance knowledge they have, and the broader their professional vision is. In student cultivation process, teachers need to teach dance knowledge, dance movements, and dance skills to students, help them expand their professional vision, cultivate their interests in dance learning, and stimulate their learning initiative. As a result, dance teachers with higher-level teaching ability tend to have better teaching performance; on the contrary, dance teachers with lower-level teaching ability can hardly achieve the expected teaching effects. Therefore, to improve the teaching effect of dance courses, we need to lay emphasis on the cultivation of the teaching ability of dance teachers. 


\subsection{Formulation of teaching management system}

The teaching content of dance courses is diverse, including many professional contents and fields, therefore, in the teaching process of dance courses, all kinds of teaching carriers, subjects and objects are involved, and how to effectively manage the manpower, material and financial resources related to these complex teaching carriers, subjects and objects is of very important significance. In this context, a good teaching management system can guarantee the order of dance teaching activities, and point out the right direction for formulating teaching tasks and plans of dance courses. Therefore, building a sound teaching management system of dance courses is very conducive to the implementation of the teaching activities of dance courses, and the system will play an indispensable role in promoting the teaching ability of dance courses. Formulating a sound teaching management system for dance courses needs to comprehensively consider relevant factors in the teaching process of dance courses, and investigate multiple aspects such the development of the dance major, the construction of dance courses, and the employment of dance major students, etc.; in this way, we can formulate a set of dance major teaching management system that fits the actual situations of dance teaching administrators, dance teachers and dance students.

\subsection{Utilization of teaching methods and teaching tools}

In student cultivation process, the dance major needs to not only impart dance knowledge, but also train their students from multiple aspects such as dance skills, dance movements, musical sense, body coordination, physical function, cultural knowledge, and cognitive ability, etc., which requires the dance major to balance all the above-mentioned teaching contents. It can be seen that the teaching content of dance courses is very rich and diversified, therefore the teaching process of dance major is a very complex knowledge imparting process; moreover, with the development and advancement of modern social science and technology, intelligent technologies are playing an increasingly important role in the teaching process, and new-type teaching modes and methods are constantly and updating. If intelligent teaching tools and methods can be effectively integrated into the teaching process of dance courses, and intelligent teaching modes can be promoted, it will be more conducive to improving the teaching effect of dance courses.

\section{Influencing factors of the teaching ability of dance courses}

The teaching ability of dance courses has many manifestations. To effectively improve the teaching ability of dance courses, it is necessary to comprehensively consider its essential problems and find out the right strategies and ways to deal with them. Judging from the current teaching process of dance courses, the authors of this paper hold that, the factors affecting the teaching ability of dance courses are mainly reflected in the following aspects: 


\subsection{Insufficient understanding and attention to the teaching goals of dance courses}

In the context of modern education, the teaching goals of dance major in various schools are quite different, especially in the different implementation stages of quality education, the training plans formulated by different schools for dance major are quite different as well. From the perspective of school administrators and teachers, some schools may focus on the training of dance skills, some pay more attention to the professional quality of dance students, and some emphasize the integration of professional knowledge and technical skills. From the perspective of dance students, some students concentrate on the development of the dance profession and the improvement of their own professional abilities, some lay more emphasis on the employment. All these differences have resulted in that the teaching goals and learning objectives of dance major administrators, teachers and students are not clear enough, their emphasis on the development of the teaching of dance major is insufficient, which has greatly affected the teaching ability of dance courses.

\subsection{Imperfect teaching management system and dance curriculum system}

The current dance teaching management system addresses more attention on the teaching performance of teachers, while ignoring the management and organization of teaching activities, such as adopting expert supervision, teacher peer review, teaching effect evaluation by students, and other methods to evaluate the teaching ability of dance courses; as for aspects such as how to regulate the teaching activities of dance courses, how to optimize the dance curriculum system, how to build a dance major teaching organization framework, how to construct an incentive mechanism for the teaching of dance courses, how to formulate learning standards of dance major students, and how to form management standards of dance education administrators, there're much rooms for further improvement. At the same time, due to the imperfectness of the dance teaching management system, different education administrators often have different teaching goals and plans, which has resulted in that the teaching goals and plans of the dance major keep changing all the time, lacking of continuity, and thus affecting the sustainable development of the dance curriculum system and the teaching ability of dance courses.

\subsection{Incompetent teaching ability of professional teachers and faculties}

The rich and diverse teaching content of dance courses requires that the professional dance teachers should have high-level teaching ability, which is reflected in several aspects: dance teachers should have rich theoretical knowledge reserves, solid practical skills, and broad professional vision; moreover, they should have the ability to integrate multiple disciplines, and a keen insight to seize opportunities in the professional field; at the same time, dance teaching is often carried out in certain cultural background, besides requirements in body shape, temperament, and mental state, dancers are often required to have certain cultural literacy and social experience, so 
that they can better express the essence of dance. In addition, the teaching ability of dance teachers is closely related to the faculty construction of dance major, and lowlevel teaching ability of dance teachers will have an impact on the construction of dance teaching faculty, the dance teaching works cannot be carried out effectively, and the introduction of professional dance talents will be compromised. Further, a low-level dance teaching faculty can hardly improve the teaching ability of dance courses, and thus forming a vicious circle.

\subsection{Insufficient teaching reform innovativeness and non-ideal teaching atmosphere}

The formulation of the teaching goals and the imparting of teaching content generally have obvious characteristics of the times, therefore, with the continuous development and progress of modern society, the teaching goals and contents of dance courses should be adjusted continuously in accordance with the requirements of social development and the characteristics of the times. However, with the changes in the teaching goals and contents of dance courses, the corresponding teaching schemes, plans, tasks, activities and progress should be adjusted accordingly. Especially with the rapid development of modern science and technology, modern education technologies have been extensively applied in dance teaching; the traditional teaching methods, tools and contents can no longer satisfy the requirements of modern education, which urges the teaching of dance major to reform and innovate continuously, so that the teaching contents, methods and goals could better fit the requirements of the times and the teaching tools could be more intelligent, and in this way, we could create a better teaching environment for dance courses and accelerate the improvement of the teaching ability of dance courses.

\subsection{Scant basic investment in dance teaching and insufficient sustainable development}

Although modern education policy has begun to vigorously promote the qualityoriented education and dance education is an important part of it, the dance major is still an unheeded major compared with other engineering majors, economic majors, and science majors. In the discipline building process, the basic investment obtained by dance major is quite limited, which has a great impact on the teaching of dance courses in all aspects such as construction of software and hardware facilities, introduction of senior talents, high-level academic exchanges, as well as teaching reform and innovation, etc., and it cannot make the dance profession to develop sustainably. Therefore, basic investment in dance teaching is an important guarantee for the improvement of the quality of dance courses, and increasing basic investment in dance teaching is an important condition for enhancing the teaching ability of dance courses. 


\subsection{Poor teaching effect of dance courses and inactive dance learning motivation of students}

Another factor that affects the teaching ability of dance courses is the learning enthusiasm and interest of dance major students. A high-level learning initiative and interest of dance students will enhance their autonomous learning ability, which is more conducive to the absorption and digestion of dance knowledge; and a low-level learning initiative and interest of dance students can only form a mechanical indoctrination teaching method, in such case, students cannot absorb the knowledge effectively, and the teaching effect of dance courses will be weakened. In addition, the classroom atmosphere of dance courses also has a direct impact on the learning enthusiasm and interest of dance students, an energetic and active teaching atmosphere can make students better accept the teaching ideas of teachers, thus striking a chord in both teachers and students, forming a kind of benign teaching interaction, and achieving good teaching effect of dance courses. Therefore, how to create a good classroom teaching atmosphere and trigger students' learning motivation is also very important for the improvement of the teaching ability of dance courses.

\section{Evaluation Index Systems for the Teaching Ability of Dance Courses}

\subsection{Principles for evaluation index selection}

To accurately analyze the teaching ability of dance courses and evaluate the teaching ability levels, the specific teaching implementation situations of dance courses need to be taken into account to construct a set of scientific, reasonable and practical evaluation system. The key to the construction of EIS (evaluation index system) of the teaching ability of dance courses is the selection of appropriate evaluation indices. As mentioned above, the teaching ability of dance courses is affected by many influencing factors, therefore the selection of evaluation indices is a complex task, for this reason, this paper holds that the selection of evaluation indices must follow some selection principles, including the principles of scientific, objective, targeted, comprehensive, and easy-to-operate. The scientific principle means that the selected evaluation indices should have clear scientific meanings; the objective principle means that the selection of evaluation indices should be based on the actual conditions, not subjective assumptions; the targeted principle means that the selected evaluation indices should target at the essential issues of the teaching ability of dance courses; the comprehensive principle means that selected evaluation indices should be able to reflect all aspects of the evaluation; and the easy-to-operate principle means that the selected evaluation indices could be quantified easily.

Under the guidance of the above evaluation index selection principles, from the four perspectives of teaching ability, teaching implementation, student learning ability cultivation and teaching effect, a few corresponding EISs have been constructed in the paper as follows: 


\subsection{EIS based on teaching ability}

Based on the teaching ability of dance courses, an EIS was constructed to evaluate the comprehensive abilities of dance teachers during the teaching of dance courses, including three aspects: basic professional ability, teaching reform and innovation ability, and teaching integration ability. The specific content is shown in Table 1.

Table 1. EIS based on teaching ability

\begin{tabular}{|c|c|c|}
\hline Sub-system & Primary index & Secondary index \\
\hline \multirow{11}{*}{$\begin{array}{l}\text { EIS based on teach- } \\
\text { ing ability }\end{array}$} & \multirow{4}{*}{ Basic professional ability } & Profession knowledge reserve and level \\
\hline & & Professional reputation \\
\hline & & Academic expansion ability \\
\hline & & Teaching organization ability \\
\hline & \multirow{4}{*}{$\begin{array}{l}\text { Teaching reform and inno- } \\
\text { vation ability }\end{array}$} & Teaching planning ability \\
\hline & & Teaching innovation ability \\
\hline & & Teaching practicalness \\
\hline & & Teaching systematicness \\
\hline & \multirow{3}{*}{ Teaching integration ability } & Ability to integrate knowledge of multiple disciplines \\
\hline & & Ability to integrate theory with practice \\
\hline & & Ability to integrate teaching with scientific research \\
\hline
\end{tabular}

\subsection{EIS based on teaching implementation}

Based on the teaching implementation of dance courses, an EIS was constructed to evaluate the specific performance of dance teachers during the teaching implementation process of dance courses, including three aspects of teaching method, teaching process, and classroom performance. The specific content is shown in Table 2.

Table 2. EIS based on teaching implementation

\begin{tabular}{|c|c|c|}
\hline Sub-system & Primary index & Secondary index \\
\hline \multirow{10}{*}{$\begin{array}{l}\text { EIS based on teach- } \\
\text { ing implementation }\end{array}$} & \multirow{3}{*}{ Teaching method } & Richness of teaching content \\
\hline & & Advancement of teaching method \\
\hline & & Intelligence of teaching method \\
\hline & \multirow{4}{*}{ Teaching process } & Teaching scheme formulation \\
\hline & & Syllabus planning \\
\hline & & Implementation of teaching tasks \\
\hline & & Completion of teaching tasks \\
\hline & \multirow{3}{*}{ Classroom performance } & Teaching attitude \\
\hline & & Teaching interactivity \\
\hline & & Classroom teaching atmosphere \\
\hline
\end{tabular}

\subsection{EIS based on student learning ability cultivation}

Based on the student learning ability cultivation, an EIS was constructed to evaluate students' performance during the learning process of dance courses, including two 
aspects of innovation ability cultivation and autonomous learning ability cultivation. The specific content is shown in Table 3.

Table 3. EIS based on student learning ability cultivation

\begin{tabular}{|c|c|c|}
\hline Sub-system & Primary index & Secondary index \\
\hline \multirow{6}{*}{$\begin{array}{l}\text { EIS based on teaching } \\
\text { student learning ability } \\
\text { cultivation }\end{array}$} & \multirow{3}{*}{$\begin{array}{l}\text { Innovation ability cultiva- } \\
\text { tion }\end{array}$} & Ability to innovate independently \\
\hline & & Ability to expand the profession \\
\hline & & Ability to think innovatively \\
\hline & \multirow{3}{*}{$\begin{array}{l}\text { Autonomous learning } \\
\text { ability cultivation }\end{array}$} & Ability to discover problems \\
\hline & & Ability to summarize problems \\
\hline & & Ability to solve problems \\
\hline
\end{tabular}

\subsection{EIS based on teaching effect}

Based on the teaching effect, an EIS was constructed to evaluate the teaching and learning results obtained by dance teachers and students, including two aspects of student performance and teacher performance. The specific content is shown in Table 4.

Table 4. EIS based on teaching effect

\begin{tabular}{|c|c|c|}
\hline Sub-system & Primary index & Secondary index \\
\hline \multirow{21}{*}{$\begin{array}{l}\text { EIS based on teach- } \\
\text { ing effect }\end{array}$} & \multirow{11}{*}{ Student performance } & Dance skills \\
\hline & & Dance movements \\
\hline & & Musical sense \\
\hline & & Body coordination \\
\hline & & Physical functions \\
\hline & & Pass rate of professional courses \\
\hline & & Excellent rate of professional courses \\
\hline & & Participation in professional competitions \\
\hline & & Winning rate of professional competitions \\
\hline & & Participation in social practice \\
\hline & & Social satisfaction \\
\hline & \multirow{10}{*}{ Teacher performance } & Number of education reform projects responsible \\
\hline & & $\begin{array}{l}\text { Number of award-winning education reform projects } \\
\text { responsible }\end{array}$ \\
\hline & & Professional textbook compilation \\
\hline & & Excellent course creation \\
\hline & & $\begin{array}{l}\text { Number of published high-level papers concerning } \\
\text { teaching reforms }\end{array}$ \\
\hline & & Number of scientific research programs responsible \\
\hline & & Student satisfaction \\
\hline & & Supervisor satisfaction \\
\hline & & Construction of key professional research office \\
\hline & & Construction of professional faculty team \\
\hline
\end{tabular}




\section{Evaluation model of the Teaching Ability of Dance Courses}

\subsection{Standardization of evaluation indices}

According to above analysis, there are many types of evaluation indices for the teaching ability of dance courses. To improve the accuracy and reliability of the evaluation results of the teaching ability of dance courses, these evaluation indices need to be normalized. Roughly, the evaluation indices can be divided into two categories, qualitative evaluation indices and quantitative evaluation indices, and evaluation indices of each category often include positive indices, negative indices and other forms. Through investigation and survey, statistical analysis, expert judgement and other methods, initial data of the qualitative and quantitative evaluation indices were obtained; for the convenience of discussion, it's assumed that there're $n$ evaluation indices, the initial data of evaluation object $\mathrm{O}$ with respect to the $\mathrm{j}$-th evaluation index is $V_{j}(O)=\left[v_{j}^{a}(O), v_{j}^{b}(O)\right], v_{j}^{a}(O) \leq v_{j}^{b}(O)$. If the threshold interval of the $\mathrm{j}$-th evaluation index is $V_{j}(\Omega)=\left[v_{j}^{a}(\Omega), v_{j}^{b}(\Omega)\right]$, then $v_{j}^{a}(\Omega) \leq v_{j}^{b}(\Omega)$.

If the $\mathrm{j}$-th evaluation index is a positive index, the normalized data of evaluation object $\mathrm{O}$ with respect to the $\mathrm{j}$-th evaluation index is $\mathrm{Uj}(\mathrm{O})$, namely:

$$
\begin{gathered}
U_{j}(O)=\left[u_{j}^{a}(O), u_{j}^{b}(O)\right]=\left[\frac{v_{j}^{a}(O)-v_{j}^{a}(\Omega)}{v_{j}^{b}(\Omega)-v_{j}^{a}(\Omega)} \frac{v_{j}^{b}(O)-v_{j}^{a}(\Omega)}{v_{j}^{b}(\Omega)-v_{j}^{a}(\Omega)}\right] \\
u_{j}^{a}(O) \leq u_{j}^{b}(O), 1 \leq j \leq n
\end{gathered}
$$

If the $\mathrm{j}$-th evaluation index is a negative index, the normalized data of evaluation object $\mathrm{O}$ with respect to the $\mathrm{j}$-th evaluation index is $\mathrm{Uj}(\mathrm{O})$, namely:

$$
U_{j}(O)=\left[u_{j}^{a}(O), u_{j}^{b}(O)\right]=\left[\frac{v_{j}^{b}(\Omega)-v_{j}^{a}(O)}{v_{j}^{b}(\Omega)-v_{j}^{a}(\Omega)}, \frac{v_{j}^{b}(\Omega)-v_{j}^{b}(O)}{v_{j}^{b}(\Omega)-v_{j}^{a}(\Omega)}\right]
$$

After normalization, all the evaluation indices of the teaching ability of dance courses had the same evaluation scale, therefore, the evaluation of the teaching ability of dance courses had a unified analysis standard, and the evaluation results could be more accurate and reliable.

\subsection{Weights of evaluation indices}

According to the information theory, the size of the information entropy value of complex system indices indicates the stability of the system, that is, it reflects the degree of the effect of system indices on the stability of the complex system [21-23]. Therefore, based on relevant principles of information theory, the evaluation of the teaching ability of dance courses can be regarded as a complex decision-making system, and the information entropy value of each evaluation index can reflect the im- 
portance of this evaluation index. Then, by calculating the information entropy values of the evaluation indices, the weights of these indices could be obtained.

If there are $m$ evaluation objects, through the above-mentioned normalization processing, the normalized data of the $\mathrm{j}$-th evaluation index of the $\mathrm{i}$-th evaluation object is $\operatorname{Uij}(\mathrm{O})$, that is:

$$
U_{i j}(O)=\left[u_{i j}^{a}(O), u_{i j}^{b}(O)\right], u_{i j}^{a}(O) \leq u_{i j}^{b}(O), 1 \leq i \leq m, 1 \leq j \leq n
$$

Then, there are:

$$
\begin{gathered}
P_{i j}=U_{i j}(O) / \sum_{i=1}^{m} U_{i j}(O) \\
E_{j}=-\frac{1}{\ln m} \sum_{i=1}^{m}\left(P_{i j} * \ln \left(P_{i j}\right)\right)
\end{gathered}
$$

If there is $P i j=0$, it's defined that:

$$
\lim _{P_{i j} \rightarrow 0}\left(P_{i j} * \ln P_{i j}\right)=0
$$

Then, the relative weight of the $\mathrm{j}$-th evaluation index of the teaching ability of dance courses is $\mathrm{wj}$, namely:

$$
w_{j}=\frac{1-E_{j}}{\sum_{j=1}^{n}\left(1-E_{j}\right)}
$$

\subsection{Evaluation model based on grey cluster analysis}

According to the actual situations of dance course teaching ability evaluation, based on the teaching management rules and regulations of dance major, the opinions and suggestion of experts, dance education administrators and professional dance teachers were consulted to determine the evaluation levels of the teaching ability of dance courses. In view of the universality of the discussion, this paper assumed that there're $\mathrm{K}$ evaluation levels for the teaching ability of dance courses, and smaller $\mathrm{K}$ values indicate stronger teaching ability of dance courses.

Based on the grey system theory [24-26], for the j-th evaluation index of the teaching ability of dance courses, its grey-number Whitening Weight Function (WWF) with respect to the $\mathrm{k}$-th $\mathrm{k}(1 \leq \mathrm{k} \leq \mathrm{K})$ evaluation level generally has four forms; assume the turning point of the corresponding gray-number WWFs was $r_{j k}^{a}, r_{j k}^{b}, r_{j k}^{c}$ and $r_{j k}^{d}$, respectively, then the typical WWF $\vartheta_{j k}\left(\bar{U}_{j}(O)\right)$ of the j-th evaluation index with respect to the $\mathrm{k}$-th evaluation level can be expressed as: 


$$
\vartheta_{j k}\left(\bar{U}_{j}(O)\right)=\left\{\begin{array}{lc}
0 & \bar{U}_{j}(O) \leq r_{j k}^{a} \cup \bar{U}_{j}(O) \geq r_{j k}^{d} \\
\frac{\bar{U}_{j}(O)-r_{j k}^{a}}{r_{j k}^{b}-r_{j k}^{a}} & \bar{U}_{j}(O) \subset\left[r_{j k}^{a}, r_{j k}^{b}\right] \\
\frac{r_{j k}^{d}-\bar{U}_{j}(O)}{r_{j k}^{d}-r_{j k}^{c}} & \bar{U}_{j}(O) \subset\left[r_{j k}^{c}, r_{j k}^{d}\right] \\
1 & \bar{U}_{j}(O) \subset\left[r_{j k}^{b}, r_{j k}^{c}\right]
\end{array}\right.
$$

where, $\bar{U}_{j}(O)=\left(u_{j}^{a}(O)+u_{j}^{b}(O)\right) / 2$.

In particular, when there are only two turning points $r_{j k}^{c}$ and $r_{j k}^{d}, \vartheta_{j k}\left(\bar{U}_{j}(O)\right)$ is the lower-limit measure WWF, its calculation model is:

$$
\vartheta_{j k}\left(\bar{U}_{j}(O)\right)= \begin{cases}0 & \bar{U}_{j}(O) \geq r_{j k}^{d} \\ \frac{r_{j k}^{d}-\bar{U}_{j}(O)}{r_{j k}^{d}-r_{j k}^{c}} & \bar{U}_{j}(O) \subset\left[r_{j k}^{c}, r_{j k}^{d}\right] \\ 1 & \bar{U}_{j}(O) \leq r_{j k}^{c}\end{cases}
$$

When there are only three turning points $r_{j k}^{a}, r_{j k}^{b}$ and $r_{j k}^{d}, \vartheta_{j k}\left(\bar{U}_{j}(O)\right)$ is the triangle measure WWF, and its calculation model is:

$$
\vartheta_{j k}\left(\bar{U}_{j}(O)\right)=\left\{\begin{array}{lc}
0 & \bar{U}_{j}(O) \leq r_{j k}^{a} \cup \bar{U}_{j}(O) \geq r_{j k}^{d} \\
\frac{\bar{U}_{j}(O)-r_{j k}^{a}}{r_{j k}^{b}-r_{j k}^{a}} & \bar{U}_{j}(O) \subset\left[r_{j k}^{a}, r_{j k}^{b}\right] \\
\frac{r_{j k}^{d}-\bar{U}_{j}(O)}{r_{j k}^{d}-r_{j k}^{b}} & \bar{U}_{j}(O) \subset\left[r_{j k}^{b}, r_{j k}^{d}\right]
\end{array}\right.
$$

When there are only two turning points $r_{j k}^{a}$ and $r_{j k}^{b}, \vartheta_{j k}\left(\bar{U}_{j}(O)\right)$ is the upper-limit measure WWF, its calculation model is:

$$
\vartheta_{j k}\left(\bar{U}_{j}(O)\right)= \begin{cases}0 & \bar{U}_{j}(O) \leq r_{j k}^{a} \\ \frac{\bar{U}_{j}(O)-r_{j k}^{a}}{r_{j k}^{b}-r_{j k}^{a}} & \bar{U}_{j}(O) \subset\left[r_{j k}^{a}, r_{j k}^{b}\right] \\ 1 & \bar{U}_{j}(O) \geq r_{j k}^{b}\end{cases}
$$

According to the construction process of the grey--number WWF and the divided evaluation levels of the teaching ability of dance courses, the WWF of the first evalu- 
ation level should adopt the lower-limit measure WWF, and the WWF of the K-th evaluation level should adopt the upper-limit measure WWF, and the WWFs of all evaluation levels in the middle should adopt the triangle measure WWF. As a result, according to the established WWF calculation model of each evaluation level, the gray clustering coefficient $\vartheta_{j k}\left(\bar{U}_{j}(O)\right)$ between the j-th evaluation index and the k-th evaluation level of evaluation object $\mathrm{O}$ can be obtained.

According to the entropy method, the weight wj of the $\mathrm{j}$-th evaluation index can be obtained, then for evaluation object $\mathrm{O}$, the grey weighted correlation degree $\varphi_{k}\left(\bar{U}_{j}(O)\right)$ between all evaluation indices and the k-th evaluation level is:

$$
\varphi_{k}\left(\bar{U}_{j}(O)\right)=\sum_{j=1}^{n}\left(w_{j} * \vartheta_{j k}\left(\bar{U}_{j}(O)\right)\right)
$$

If there is:

$$
\varphi_{s}\left(\bar{U}_{j}(O)\right)=\max _{1 \leq k \leq K}\left(\varphi_{k}\left(\bar{U}_{j}(O)\right)\right), 1 \leq s, k \leq K
$$

It means that the evaluation level of evaluation object $\mathrm{O}$ is Level s.

\section{Conclusion}

This paper discussed the improvement of the teaching ability of dance courses, analyzed the connotation and essential features of the teaching ability of dance major courses, and explored factors that can influence the improvement of the teaching ability of dance courses. Then on this basis, this paper established a series of EISs and an improved model for the evaluation of the teaching ability of dance courses, which not only pointed out the direction for improving the teaching ability of dance courses, but also gave specific models for the quantitative analysis of the teaching ability of dance courses. The research of this paper provided a good reference for the analysis of the teaching ability of dance courses and the courses of other similar disciplines.

\section{$7 \quad$ Acknowledgement}

"New Path to Improve the Quality of Social Dance Education in Heilongjiang Province", Major Art Science Planning Project, Heilongjiang Province China

\section{References}

[1] Peña-Ayala, A., Villegas-Berumen, H.G. (2020). Evaluation of the influence that higher education boosts on students' entrepreneurial proclivity: Evidence from Mexico and Spain. The International Journal of Management Education, 18(3): 100404. https://doi.org/10. 1016/j.ijme.2020.100404. 
[2] Király, G., Géring, Z. (2019). Introduction to 'Futures of Higher Education'special issue. Futures, 111: 123-129. https://doi.org/10.1016/j.futures.2019.03.004 .

[3] Yassen, M. (2018). Research on the current situation of integrating aerobics into junior middle school physical education and the cultivation of teachers' teaching ability. Charming China, 2018(15): 96-97. https://doi.org/10.3969/j.issn.1673-0992.2018.15.076 .

[4] Zhao, S.G. (2016). A study on the predicament and strategy of effective teaching of sports dance course in college physical education major. Journal of Chaohu College, 18(6): 137142+153. https://doi.org/10.3969/j.issn.1672-2868.2016.06.030.

[5] Cheng, S.P. (2020). The Optimization and Interaction Analysis of Dance Education Curriculum. The Guide of Science \& Education, 2020(9): 63-64. http://dx.doi.org/10. 16400/j.cnki.kjdks.2020.09.031.

[6] Li, H.G., Guo, S.H. (2020). Research on quality education in sports dance education [J]. Contemporary Sports Technology, 10(10): 142-143. https://doi.org/10.16655/j.cnki.20952813.2020.10.142.

[7] Jiang, Y. (2019). Reform and Development of Dance Teaching in University. Art Research Letters, 8(01): 1-4. https://doi.org/ 10.12677/ARL.2019.81001 .

[8] Zhang, H. (2020). Exploration on the Construction of Teaching Content System of Cheerleading Course in Colleges and Universities. Bulletin of Sport Science \& Technology, 28(9): 50, 160. https://doi.org/10.19379/j.cnki.issn.1005-0256.2020.09.024 .

[9] Tang, S.H. (2019). Research on the methods of improving the dance teaching ability of Preschool Normal Students. Comparative Study of Cultural Innovation, 2019(3): 75-76. https://doi.org/10.3969/j.issn.2096-4110.2019.03.034

[10] Shi, J.Y. (2018). Analysis on the Improvement of Dancing Creation Ability and Teaching Innovation Strategy in Higher Vocational Colleges. Journal of Hubei Correspondence University, 31(17): 145-146. https://doi.org/10.3969/j.issn.1671-5918.2018.17.066 .

[11] Pastore, S., Pentassuglia, M. (2015). Teaching as dance: A case-study for teacher practice analysis. International Journal of Educational Research, 70: 16-30. http://dx.doi.org/10.10 16/j.ijer.2014.12.001

[12] Shi, Y.Y. (2016). An Investigation of Sports Dancing Education Assessment. Journal of Chengdu Normal University, 32(3): 31-36. http://dx.doi.org/10.3969/j.issn.2095-5642.20 16.03.031.

[13] Guo, B. (2020). Analysis on influencing factors of dance teaching effect in colleges based on data analysis and decision tree model, International Journal of Emerging Technologies in Learning, 15(9): 245-257.

[14] Wang, Y., Zheng, G. (2020). Application of artificial intelligence in college dance teaching and its performance analysis, International Journal of Emerging Technologies in Learning, 15(16): 178-190.

[15] Hilali-Jaghdam, I., Ishak, A.B., Abdel-Khalek, S., Jamal, A. (2020). Quantum and classical genetic algorithms for multilevel segmentation of medical images: A comparative study. Computer Communications, 162: 83-93. https://doi.org/10.1016/j.comcom.2020.08.010

[16] Ramón, N., Ruiz, J.L., Sirvent, I. (2020). Cross-benchmarking for performance evaluation: Looking across best practices of different peer groups using DEA. Omega, 92: 102169. https://doi.org/10.1016/j.omega.2019.102169.

[17] Allahverdyan, A.E., Galstyan, A., Abbas, A.E., Struzik, Z.R. (2018). Adaptive decision making via entropy minimization. International Journal of Approximate Reasoning, 103: 270-287. https://doi.org/10.1016/j.ijar.2018.10.001 .

[18] Chukwumaobi, O., Akinlabi, E.T., Njoku, H.O. (2020). Selection of phase change material for improved performance of Trombe wall systems using the entropy weight and TOPSIS 
methodology. Energy and Buildings, 109967. https://doi.org/10.1016/j.enbuild.2020.1099 67 .

[19] Alfaro-Saiz, J.J., Bas, M.C., Giner-Bosch, V., Rodríguez-Rodríguez, R., Verdecho, M.J. (2020). An evaluation of the environmental factors for supply chain strategy decisions using grey systems and composite indicators. Applied Mathematical Modelling, 79: 490505. https://doi.org/10.1016/j.apm.2019.10.048 .

[20] Kumar, J., Soota, T. (2020). Multi-response optimization of machining parameter for Zircaloy by response surface methodology and grey relation analysis. Materials Today: Proceedings, 21: 1544-1550. https://doi.org/10.1016/j.matpr.2019.11.084 .

[21] Karagiannis, R., Karagiannis, G. (2020). Constructing composite indicators with Shannon entropy: The case of Human Development Index. Socio-Economic Planning Sciences, 70: 100701. https://doi.org/10.1016/j.seps.2019.03.007.

[22] Cavallaro, F., Zavadskas, E.K., Streimikiene, D., Mardani, A. (2019). Assessment of concentrated solar power (CSP) technologies based on a modified intuitionistic fuzzy topsis and trigonometric entropy weights. Technological Forecasting and Social Change, 140: 258-270. https://doi.org/10.1016/j.techfore.2018.12.009.

[23] Attarakih, M., Bart, H.J., Abu-Khader, M. (2019). On the solution of the population balance equation: From global to local constrained maximum entropy method. Chemical Engineering Science, 209: 115168. https://doi.org/10.1016/j.ces.2019.115168 .

[24] Zhao, B., Ren, Y., Gao, D., Xu, L. (2019). Performance ratio prediction of photovoltaic pumping system based on grey clustering and second curvelet neural network. Energy, 171: 360-371. https://doi.org/10.1016/j.energy.2019.01.028 .

[25] Delgado, A., Romero, I. (2016). Environmental conflict analysis using an integrated grey clustering and entropy-weight method: A case study of a mining project in Peru. Environmental Modelling \& Software, 77: 108-121. http://dx.doi.org/10.1016/j.envsoft.20 15.12 .011 .

[26] Karakoç, Ö., Es, H.A., Fırat, S.Ü. (2019). Evaluation of the development level of provinces by grey cluster analysis. Procedia Computer Science, 158: 135-144. https://doi. org/10.1016/j.procs.2019.09.036.

\section{$9 \quad$ Author}

Fubo Ma a member of the Chinese Dancers Association and often serves as judges in various national and provincial-level professional dance competitions, a reviewer expert of social art education in Heilongjiang Province, a celebrity artist, famous choreographer, and influential dance educator and director (email: fuboma@126.com).

Article submitted 2020-12-17. Resubmitted 2021-01-03. Final acceptance 2021-01-05. Final version published as submitted by the authors. 